\title{
Feeding habits of the false southern king crab Paralomis granulosa (Lithodidae) in the Beagle Channel, Tierra del Fuego, Argentina*
}

\author{
LAURA INÉS COMOGLIO and OSCAR ANTONIO AMIN \\ Centro Austral de Investigaciones Científicas (CADIC-CONICET), CC92, 9410 Ushuaia, Tierra del Fuego, Argentina
}

\begin{abstract}
SUMMARY: Stomach contents of 282 false southern king crabs (Paralomis granulosa), between 10 to $90 \mathrm{~mm}$ CL from the Beagle Channel (Golondrina Bay and Roca Mora), Argentina, were examined by the frequency of occurrence method of analysis and by a food index. Roca Mora is an area where juveniles $(<50 \mathrm{~mm} \mathrm{CL})$ dominate and in Golondrina Bay adults $(>60 \mathrm{~mm}$ CL) are common; in this last area sexual segregation was also observed. The principal food groups for crabs of Golondrina Bay were algae, molluscs, crustaceans, bryozoans and foraminiferans; for crabs from Roca Mora the natural diet consisted of three major food groups: hydrozoans, echinoderms and foraminiferans. The relative frequency of different prey groups varied in relation to the size, season and sex. There were no significant differences in the quantity of food consumed by sexes in both areas. Generally small crabs $(<40 \mathrm{~mm}$ CL) contained more food than large crabs $(>50 \mathrm{~mm} \mathrm{CL})$. Juveniles consumed a greater amount of food during winter and spring. In summer (moulting period), juveniles had the highest vacuity index. Adults consumed minor amounts of food during autumn, before the spawning-moulting-mating period when the vacuity index was higher (spring).
\end{abstract}

Key words: Feeding habits, natural diet, crabs, Paralomis granulosa, stomach contents, Lithodidae.

RESUMEN: Hábitos alimentarios del Centollón PARAlOMIS GRANUlosa (Lithodidae) En el Canal del Beagle, TierRa DEL Fuego, ARGENTINA. - Se analizaron 282 contenidos estomacales de centollón (Paralomis granulosa), comprendidos entre $10 \mathrm{~mm}$ y $90 \mathrm{~mm}$ de largo de caparazón (LC), provenientes del Canal del Beagle (Bahía Golondrina y Roca Mora), Argentina. El análisis se basó en la frecuencia de presencia de los grupos que conforman la dieta y el peso relativo del contenido estomacal. Roca Mora es un área dominada por juveniles (<50 mm LC) y Bahía Golondrina por adultos (>60 mm LC). En esta última se observó segregación sexual. Los principales grupos que conforman la dieta de los individuos de Bahía Golondrina fueron algas, moluscos, crustáceos, briozoos y foraminíferos; mientras que para los de Roca Mora la dieta natural comprende tres grupos principales: hidrozoos, equinodermos y foraminíferos. Las frecuencias relativas de los diferentes grupos variaron en relación a la talla, época de muestreo y sexo. No se detectaron diferencias significativas en la cantidad de alimento consumido en relación al sexo en ambas áreas. Generalmente los cangrejos pequeños ( $<40 \mathrm{~mm}$ LC) contenían más cantidad de alimento que los mayores (>50 mm LC). Los juveniles consumieron mayor cantidad de alimento durante el invierno y primavera. Durante el verano (período de muda) se determinó el mayor índice de vacuidad. Los adultos consumieron mayores cantidades de alimento durante el verano, después del período de desove-muda-apareamiento cuando el índice de vacuidad fue mayor (primavera).

Palabras clave: Hábito alimentario, dieta natural, cangrejos, Paralomis granulosa, contenido estomacal, Lithodidae, centollón.

\section{INTRODUCTION}

The false southern king crab, Paralomis granulosa (Jacquinot, 1847), commonly called "cento-

*Accepted December 11, 1998. llón", is a commercial species in Chile and Argentina since the early 1970's. For Argentina the largest catches were recorded in 1995 when they amounted to 320 metric tons. This species inhabits the Pacific Ocean from Paso Tenaún, Chile, to Cape Horn, Argentina, and the Atlantic Ocean from $56^{\circ} \mathrm{S}$ to the 
Golfo San Jorge, including the Malvinas Islands at depths of up to $50 \mathrm{~m}$ (Macpherson, 1988).

Studies on the biology are scarce (Campodónico, 1977; Campodónico and Guzmán, 1981; Campodónico et al., 1982; Vinuesa et al., 1989; Comoglio et al., 1990; Lovrich and Vinuesa, 1993). Food habits have been analyzed for numerous crab species, including Chionoecetes bairdi (see Paul et al., 1979; Jewett and Feder, 1983), Paralithodes camtschatica (Tilesius, 1815) (see Mc Laughlin and Hebard, 1961; Takeuchi, 1968; Feder and Paul, 1980; Feder and Jewett, 1981; Jewett and Feder, 1982), Callinectes sapidus Rathbun, 1896 (see Ryer, 1987; Ropes, 1988) and Lithodes santolla (Molina, 1782) (see Comoglio and Amin, 1996).

The shredding of prey by mouthparts and further mastication by the gastric mill makes identification of prey species difficult (Stevens et al., 1982). However, a study of the food habits of the crab is of considerable importance because food availability and utilization may play important roles in the distribution, migration and moulting patterns of the crabs.

This report indicates the types of organisms that contributed to the diet of Paralomis granulosa in terms of the frequency of occurrence and the amount of food in the stomachs.

\section{MATERIAL AND METHODS}

Specimens of Paralomis granulosa were collected during 1988-1989 ( $\mathrm{N=282)}$ in Golondrina Bay (40.78\%) and Roca Mora (59.57\%) (Fig. 1), by SCUBA. In the laboratory, crabs were measured (CL, carapace length, defined as the distance from the posterior margin of the orbital indentation to the mid-point of the posterior marginal indentation, in $\mathrm{mm}$ ), weighed (WT, wet weight, in g) and sexed.

Foreguts were isolated immediately and contents, when present, were removed and weighed to the nearest $0.01 \mathrm{~g}$, then fixed in $10 \%$ buffered seawater formalin. Prey organisms were identified to the lowest possible taxonomic level using a dissecting microscope.

For size comparisons, crabs were divided into 8 size classes of 10 to $19.9 \mathrm{~mm} ; 20$ to $29.9 \mathrm{~mm}$; etc., then analyzed as 8 discrete samples. The percentage frequency of occurrence $(F)$ for each prey taxon identified in the stomachs was calculated.

The Wilcoxon Signed Rank test and KruskalWallis test were used in analyzing the relative food weight of crabs (stomach content weight/body weight) by a classification factor. A P-value was calculated and if found to be less than 0.05 , a third pro-

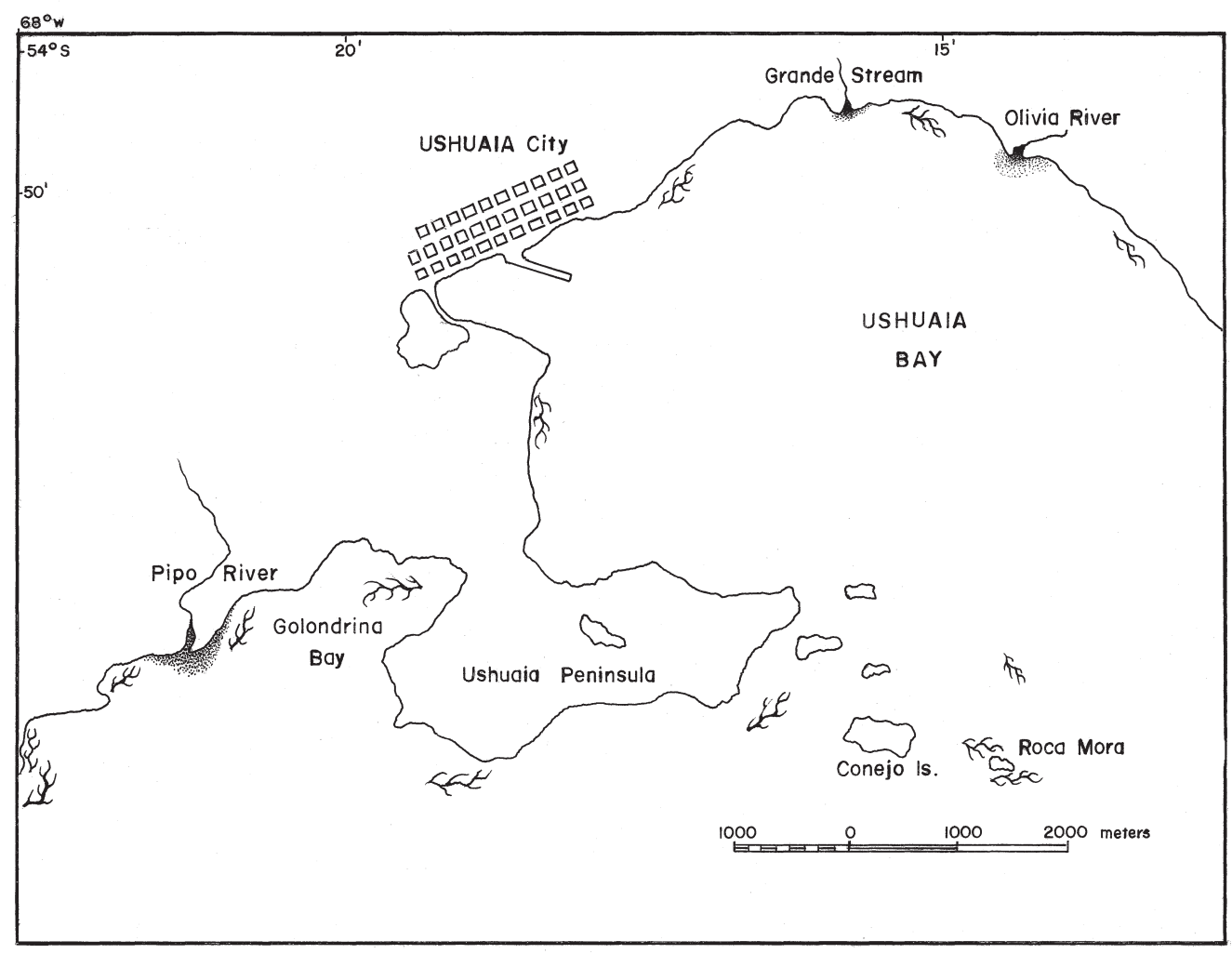

FIG. 1. - Locations where false king crabs, Paralomis granulosa, were collected for stomach analyses. 
TABLE 1. - Number of crabs with food by sampling areas, sexes and size classes.

\begin{tabular}{|c|c|c|c|c|c|c|}
\hline \multirow{2}{*}{$\begin{array}{l}\text { Size classes } \\
(\mathrm{CL} \text { in } \mathrm{mm})\end{array}$} & \multicolumn{3}{|c|}{ Golondrina Bay } & \multicolumn{3}{|c|}{ Roca Mora } \\
\hline & Male & Female & Total & Male & Female & Total \\
\hline $10-19.9$ & 0 & 0 & 0 & 11 & 9 & 20 \\
\hline $20-29.9$ & 0 & 0 & 0 & 42 & 42 & 84 \\
\hline $30-39.9$ & 0 & 0 & 0 & 12 & 6 & 18 \\
\hline $40-49.9$ & 3 & 0 & 3 & 0 & 0 & 0 \\
\hline $50-59.9$ & 4 & 3 & 7 & 1 & 7 & 8 \\
\hline $60-69.9$ & 18 & 11 & 29 & 9 & 7 & 16 \\
\hline $70-79.9$ & 27 & 8 & 35 & 0 & 0 & 0 \\
\hline $80-89.9$ & 13 & 0 & 13 & 1 & 0 & \\
\hline $90-99.9$ & 1 & 0 & 1 & 0 & 0 & \\
\hline $\begin{array}{l}\text { Total } \\
\text { examined } \\
(\%)\end{array}$ & $\begin{array}{r}65 \\
74.71\end{array}$ & $\begin{array}{r}22 \\
25.29\end{array}$ & 87 & $\begin{array}{r}76 \\
51.7\end{array}$ & $\begin{array}{r}71 \\
48.3\end{array}$ & 147 \\
\hline
\end{tabular}

cedure was employed to make multiple comparisons using the rank sums (Daniels, 1978).

\section{RESULTS}

\section{General considerations}

The overall vacuity index (percentage of empty stomachs) was $11.0 \%$. The crabs examined ranged from $10 \mathrm{~mm}$ to $99.9 \mathrm{~mm} \mathrm{CL}$ (Table 1). 17 crabs $(6.0 \%)$ with food in their stomachs were damaged and were discarded without further analysis.

Crabs $(\mathrm{N}=234)$ were analyzed taking into account the different areas. Roca Mora is an area where we principally found crabs $<40 \mathrm{~mm} \mathrm{CL}$, and few crabs with CL>50 mm (only during summer months). In Golondrina Bay specimens were principally CL $>60 \mathrm{~mm}$. The percentage of females was $25.3 \%$ for Golondrina Bay and $48.3 \%$ for Roca Mora.

\section{Natural diet}

Some species of molluscs that could be determined in the stomach contents were Mytilus edulis chilensis Hupe, 1854, Aulacomya ater Molina, 1782, Hyatella solida (Sowerby, 1834), Margarella violacea (King and Broderip, 1831), Calliostoma nudum (Phillippi, 1845) and Fissurella picta (Gmelin, 1791).

Bryozoans were only represented by Membranipora isabelleana (d'Orbingy, 1847) and echinoderms by the sea urchin Pseudechinus magellanicus (Bernasconi, 1953).

Foraminiferans were represented by 26 species, among them Bucella peruviana (d'Orbingy, 1839),
TABle 2. - Natural diet of Paralomis granulosa from the Beagle Channel. Frequency of occurrence $(\%)$ of food groups in the stomach of crabs by sexes and by sampling areas.

\begin{tabular}{cccc} 
& \multicolumn{2}{c}{ Golondrina Bay } & \multicolumn{2}{c}{ Roca Mora } \\
Prey groups $\quad$ Males Females Total Males Females Total
\end{tabular}

\begin{tabular}{lrrrrrr}
\hline Foraminifera & 40.00 & 63.64 & 45.98 & 50.00 & 43.66 & 46.94 \\
Bryozoa & 41.54 & 63.44 & 47.12 & 27.63 & 35.21 & 31.29 \\
Hydrozoa & 21.54 & 36.36 & 25.29 & 63.16 & 56.34 & 59.86 \\
Mollusca & 55.38 & 86.36 & 63.22 & 39.17 & 39.44 & 39.46 \\
Echinodermata & 15.38 & 9.09 & 13.79 & 50.00 & 43.66 & 46.94 \\
Algae & 72.31 & 59.09 & 68.97 & 19,74 & 15.49 & 17.69 \\
Polychaeta & 30.77 & 31.82 & 31.03 & 9.21 & 5.63 & 7.48 \\
$\begin{array}{l}\text { Crustacea } \\
\text { Number of }\end{array}$ & 53.85 & 31.82 & 48.28 & 9.21 & 12.68 & 10.88 \\
stomachs with food & 65 & 22 & 87 & 76 & 71 & 147 \\
& & & & & & \\
Chi-square & & 9.35 & & 56.21 & & \\
Significance level & $0.23(* *)$ & & $8.59 \mathrm{E}-10$ & & \\
\end{tabular}

Cibicides sp., Elphidium sp., Discorbis peruvianus (d'Orbingy, 1839), Cribrostomoides sp., and Trochammina sp., which are commonly found in this area (Lenna, 1966; Boltovskoy et al., 1983).

Taking into account the sampling areas, the principal food groups for crabs of Golondrina Bay were algae $(69.0 \%$ frequency of occurrence), molluscs $(63.2 \%$, principally bivalves $43.7 \%$ and gastropods $39.1 \%$ ), crustaceans $(48.3 \%)$, bryozoans $(47.1 \%)$ and foraminiferans $(46.0 \%)$. For crabs collected in Roca Mora the natural diet belonged to four major food groups: hydrozoans (59.9\%), echinoderms $(46.9 \%)$, foraminiferans $(46.9 \%)$ and molluscs $(39.5 \%$, principally gastropods $26.5 \%$ ) (Table 2).

There was no significant difference between sexes in the frequency of occurrence of the principal prey items for crabs from Roca Mora, but for Golondrina Bay significant differences occurred (Chi-

TABLE 3. - Statistical results. Wilcoxon signed-rank test for Paralomis granulosa relative food weight by sexes. a) Golondrina Bay, b) Roca Mora.

a) Golondrina Bay

\begin{tabular}{lcc} 
Sexes & $\begin{array}{c}\text { Stomachs with food } \\
\text { Number }\end{array}$ & $\begin{array}{c}\text { Average rank sum } \\
\text { of contents }\end{array}$ \\
\hline Males & 65 & 41.12 \\
Females & 21 & 50.86 \\
\hline
\end{tabular}

Calculated test statistic $=2.41$. Calculated $\mathrm{P}$-value $=0.12$.

b) Roca Mora

$\begin{array}{lll}\text { Males } & 67 & 65.08 \\ \text { Females } & 59 & 61.67\end{array}$

Calculated test statistic $=0.083$. Calculated $\mathrm{P}$-value $=0.77$ 
TABLE 4. - Natural diet of Paralomis granulosa from the Beagle Channel. Frequency of occurrence (\%) of food groups in the stomach of crabs by size classes.

\begin{tabular}{|c|c|c|c|c|c|c|c|c|}
\hline Food groups & 1 & 2 & 3 & $\begin{array}{c}\text { Size classes } \\
4\end{array}$ & 5 & 6 & 7 & 8 \\
\hline Foraminifera & 50 & 38 & 50 & 67 & 60 & 62 & 37 & 54 \\
\hline Bryozoa & 50 & 32 & 39 & 67 & 40 & 45 & 34 & 31 \\
\hline Hydrozoa & 45 & 56 & 67 & 0 & 47 & 45 & 34 & 23 \\
\hline Mollusca & 20 & 29 & 56 & 33 & 67 & 70 & 71 & 46 \\
\hline Echinodermata & 35 & 44 & 39 & 33 & 47 & 34 & 14 & 15 \\
\hline Algae & 10 & 6 & 28 & 67 & 73 & 66 & 54 & 77 \\
\hline Polychaeta & 0 & 4 & 17 & 0 & 13 & 30 & 40 & 23 \\
\hline Crustacea & 0 & 7 & 6 & 33 & 33 & 43 & 54 & 46 \\
\hline $\begin{array}{l}\text { Number of stomachs } \\
\text { with food }\end{array}$ & 20 & 84 & 18 & 3 & 15 & 47 & 35 & 13 \\
\hline
\end{tabular}

square test, see Table 2). The food weight to body weight relationships of males and females was not significantly different (Wilcoxon signed-rank test: $\mathrm{P}=0.12$ for Golondrina Bay and $\mathrm{P}=0.77$ for Roca Mora) (Table 3). Thus, food data for both sexes were combined for the analysis of quantity of food consumed. Cannibalism was not recorded in the present study.

\section{Size classes of crabs}

There were differences in the frequency of occurrence of food groups among size classes (Table 4). Molluscs had higher frequencies in size classes between 50 and $80 \mathrm{~mm}$ CL. Algae and crustaceans were present in higher frequencies in classes $>40$ $\mathrm{mm}$ CL. Foraminiferans, hydrozoans and bryozoans were present in all classes with similar frequencies. Echinoderms had higher frequencies in organisms $<70 \mathrm{~mm} \mathrm{CL}$.

The converted weight of food consumed differed significantly among crab size groups (Table 5). The smaller crabs $(C L<40 \mathrm{~mm})$ contained significantly more $(\mathrm{P}<0.05)$ food than did large crabs.
TABLE 5. - Statistical results. Kruskal-Wallis one-way ANOVA for Paralomis granulosa food weight by crab size groups.

\begin{tabular}{lcc}
\hline $\begin{array}{c}\text { Size classes } \\
(\text { CL in mm) }\end{array}$ & $\begin{array}{c}\text { Stomachs with food } \\
\text { Number }\end{array}$ & $\begin{array}{c}\text { Average rank sum } \\
\text { of contents }\end{array}$ \\
\hline $10-19.9$ & 13 & 137.92 \\
$20-29.9$ & 75 & 156.11 \\
$30-39.9$ & 17 & 143.97 \\
$40-49.9$ & 3 & 111.33 \\
$50-59.9$ & 13 & 70.15 \\
$60-69.9$ & 45 & 75.04 \\
$70-79.9$ & 34 & 53.97 \\
$80-89.9$ & 13 & 44.92 \\
$90-99.9$ & 1 & 12 \\
\hline
\end{tabular}

Calculated test statistic $=113.32$. Calculated P-value $=0$ assuming a $\chi^{2}$ distribution with $8 \mathrm{DF}$.

Pairs significantly different $(\mathrm{P}<0.20)$. Multiple comparison test (Daniels, 1978). 10-19.9; 20-29.9; 30-39.9 > 50-59.9; 60-69.9; 70$79.9 ; 80-89.9$

\section{Sampling period}

The diet of $P$. granulosa differed in terms of frequency of occurrence between areas and sampling periods (Table 6). For Golondrina Bay, there were few crabs collected in winter and during spring the vacuity index was high. Therefore for these periods

TABLE 6. - Natural diet of Paralomis granulosa from the Beagle Channel. Frequency of occurrence (\%) of food groups in the stomach of crabs by sampling periods and areas (GB: Golondrina Bay; RM: Roca Mora).

\begin{tabular}{|c|c|c|c|c|c|c|c|c|}
\hline \multirow[b]{2}{*}{ Prey groups } & \multicolumn{2}{|c|}{ Summer } & \multicolumn{2}{|c|}{ Autumn } & \multicolumn{2}{|c|}{ Winter } & \multicolumn{2}{|c|}{ Spring } \\
\hline & GB & $\mathrm{RM}$ & GB & RM & GB & $\mathrm{RM}$ & GB & $\mathrm{RM}$ \\
\hline Foraminifera & 50.79 & 56.25 & 5.88 & 19.05 & 100 & 41.30 & 100 & 59.38 \\
\hline Bryozoa & 55.56 & 16.67 & 11.76 & 42.86 & 40 & 43.48 & 100 & 28.13 \\
\hline Hydrozoa & 15.87 & 89.58 & 41.18 & 66.67 & 60 & 41.30 & 100 & 37.50 \\
\hline Mollusca & 66.67 & 47.92 & 35.29 & 28.57 & 100 & 41.30 & 100 & 31.25 \\
\hline Echinodermata & 15.87 & 54.17 & 5.88 & 28.57 & 20 & 43.48 & 0 & 53.13 \\
\hline Algae & 88.89 & 33.33 & 17.65 & 14.29 & 20 & 4.35 & 0 & 15.63 \\
\hline Polychaeta & 33.33 & 12.50 & 17.65 & 4.76 & 40 & 8.70 & 50 & 0 \\
\hline Crustacea & 44.44 & 25.00 & 64.71 & 9.52 & 40 & 2.17 & 50 & 3.13 \\
\hline Unidentified material & 11.11 & 45.83 & 47.06 & 23.81 & 0 & 34.78 & 0 & 46.88 \\
\hline Number of stomachs with food & 63 & 48 & 17 & 21 & 5 & 46 & 2 & 32 \\
\hline Vacuity index $(\%)$ & 0 & 18.64 & 10.53 & 0 & 28.57 & 0 & 85.71 & 11.11 \\
\hline
\end{tabular}


we only list the following food groups as being present without rank in importance: foraminiferans, hydrozoans, bryozoans, molluscs, crustaceans and polychaetes. In this area, during summer the principal prey groups were algae (88.9\%), molluscs $(66.7 \%)$, bryozoans $(55.6 \%)$, foraminiferans $(50.8 \%)$ and crustaceans $(44.4 \%)$. In crabs collected during autumn the principal food groups were crustaceans (64.7\%), hydrozoans (41.2\%), molluscs $(35.3 \%)$ and a higher percentage of undetermined material (47.1\%).

For Roca Mora, during summer and autumn hydrozoans $(89.6 \%$ and $66.7 \%$, respectively) were the most frequent prey, with a higher frequency than in other seasons. Others groups present in crabs during summer were foraminiferans $(56.3 \%)$, echinoderms (54.2\%) and molluscs (47.9\%). During autumn a high percentage of bryozoans $(42.9 \%)$ was observed. In winter, prey groups present had similar percentage of occurrence, bryozoans (43.5\%), echinoderms $(43.5 \%)$, foraminiferans, hydrozoans and molluscs (all with 41.3\%). In spring, foraminiferans had a higher frequency $(59.4 \%)$ and the next in occurrence was echinoderms (53.1\%). In all periods a significant percentage of unidentified material occurred (between 23\% and 47\%).

Springtime was the principal period of high vacuity for crabs from Golondrina Bay (85.71\%), and summer for crabs from Roca Mora (18.6\%) (Table 6).

TABLE 7. - Statistical results. Kruskal-Wallis one-way ANOVA for Paralomis granulosa food weight by sampling periods.

\begin{tabular}{lcc}
$\begin{array}{l}\text { a) Golondrina Bay } \\
\text { Sampling period }\end{array}$ & $\begin{array}{c}\text { Stomachs with food } \\
\text { Number }\end{array}$ & $\begin{array}{c}\text { Average rank sum } \\
\text { of contents }\end{array}$ \\
\hline Summer & 63 & 49.06 \\
Autumn & 17 & 17.53 \\
Winter & 4 & 58.25 \\
Spring & 2 & 59.50 \\
\hline
\end{tabular}

Calculated test statistic $=23.73$. Calculated $\mathrm{P}$-value $=2.84 \mathrm{E}-5$ assuming a $\chi^{2}$ distribution with $3 \mathrm{DF}$. Pairs significantly different $(\mathrm{P}<0.20)$. Multiple comparison test (Daniels, 1978). Autumn < Summer; Winter; Spring.

\begin{tabular}{lcc}
\hline $\begin{array}{l}\text { b) Roca Mora } \\
\text { Sampling period }\end{array}$ & $\begin{array}{c}\text { Stomachs with food } \\
\text { Number }\end{array}$ & $\begin{array}{c}\text { Average rank sum } \\
\text { of contents }\end{array}$ \\
\hline Summer & 45 & 53.44 \\
Autumn & 12 & 42.42 \\
Winter & 40 & 77.61 \\
Spring & 31 & 72.11 \\
\hline
\end{tabular}

Calculated test statistic $=14.36$. Calculated P-value $=2.45 \mathrm{E}-3$ assuming a $\chi^{2}$ distribution with 3 DF. Pairs significantly different $(\mathrm{P}<0.20)$. Multiple comparison test (Daniels, 1978). Summer; Autumn $<$ Winter; Spring.
In autumn, crabs from Golondrina Bay contained significantly less food than crabs from other seasons. Crabs from Roca Mora consumed more food during winter and spring (Table 7).

\section{DISCUSSION}

The frequency of occurrence is an approximate method of analysis of gut contents, utilized when a broad description of food groups is required. Comoglio and Amin (1996) discussed the utilization of this method. This method is appropiate for most kind of foods, but overestimates the importance of unidentifiable material, sand and small animals occurring frequently, but in small amounts. For example, in the present study, foraminiferans occurred in $>40 \%$ frequency of occurrence but from 1 to 4 individuals per stomach, presumably ingested incidentally while taking other prey items.

Paralomis granulosa has a diverse diet but the composition changes in relation to size of the predator and season. The results agree with Stevens et al. (1982) who determined that prey size was directly proportional to crab size and the optimum prey size increased with crab width. These authors concluded that crabs eat a representative selection of the benthos around them, that most feeding is opportunistic, and that little selection is evident.

Lovrich and Vinuesa (1993) determined that size at gonadal maturity in males is $50.2 \mathrm{~mm} \mathrm{CL}$ and in females is $60.6 \mathrm{~mm}$ CL. Therefore, we established that Roca Mora is an area where juveniles are present while in Golondrina Bay adults are present.

As had been observed by Campodónico et al. (1982) we determined a sexual segregation in adults. In Golondrina Bay the size classes $>60 \mathrm{~mm}$ CL were composed of males and in classes $<40 \mathrm{~mm} \mathrm{CL}$ in Roca Mora similar percentages of males and females were observed. Only $7.3 \%$ of the total crabs analyzed in Roca Mora were the size of maturity. These large crabs appeared only during summer, with this period being the time of greatest food consumption for adults, and the moulting period for juveniles. However, no cannibalism was observed.

In Paralomis granulosa, as in Lithodes santolla (see Comoglio and Amin, 1996), we observed that juveniles consumed more food than larger crabs, principally during winter and spring, before the moulting period (summer) when the highest vacuity index was observed. 
During spring months, the vacuity index was higher for specimens of Golondrina Bay, in agreement with the observations of Lovrich and Vinuesa (1993) as the moulting-mating period of P. granulosa. Adults consumed minor amounts of food during autumn, before the spawning period.

As occurs with $L$. santolla, feeding generally occurs throughout the year, except during a few weeks of the moulting-mating period when feeding ceases or is at a minimum.

Additional data are essential to clarify the feeding biology of this dominant crab in Beagle Channel waters. Some parameters that should be addressed include the time required for the passage of food, the frequency with which prey are taken, and the caloric content of prey. It is only when the above information is adequately addressed that we will understand the feeding dynamics of these crabs.

\section{ACKNOWLEDGEMENTS}

Special thanks to Lic. Violeta Totah, Dr. G Pastorino and Dr. J. López Gappa for help in the identification of Foraminifera, Gastropoda and Bryozoa. We are also grateful to P. Medina, M. Garcia, C. Cantu, R. Pastorino and H. Monsalve for diving and help in the fieldwork. This study was supported by the Consejo Nacional de Investigaciones Cientificas y Técnicas (CONICET).

\section{REFERENCES}

Boltovskoy, E., G. Giussani de Kahn and S. Watanabe. - 1983. Variaciones estacionales y standing crop de los foraminíferos bentónicos de Ushuaia, Tierra del Fuego. Physis, Secc. A, 41 (101): 113-127.

Campodónico, I. - 1977. Algunos aspectos biológico-pesqueros del recurso centollón Paralomis granulosa (Jacquinot) (Decapoda, Anomura, Lithodidae) en el Estrecho de Magallanes. Ans. Inst. Pat. 8: 363-373.

Campodónico, I. and M. Guzmán. - 1981. Larval development of Paralomis granulosa (Jacquinot) under laboratory conditions
(Decapoda, Anomura, Lithodidae). Crustaceana, 40: 272-285. Campodónico, I., M.B. Hernández and E. Riveros. - 1982. Investigación, manejo y control de las pesquerías de centolla y centollón de la XIIa Región. I Etapa Temporada 1982-83 (FebreroAbril). Informe Inst. Pat., 10: 1-41.

Comoglio, L., J. Vinuesa and G. Lovrich. - 1990. Feeding habits of Southern King Crab, Lithodes santolla (Molina), and the False King Crab, Paralomis granulosa, Jacquinot, in the Beagle Channel. In: Proc. Int. Symp. King and Tanner Crabs, 1989, pp. 315-325. Alaska Sea Grant College Program Rep. AK-SG-9004.

Comoglio, L. and O. Amin. - 1996. Natural diet of the southern king crab, Lithodes santolla (Lithodidae) in the Beagle Channel, Tierra del Fuego, Argentina. Biol. Pesquera, 25: 51-57 (1996).

Daniels, W. - 1978. Applied nonparametric statistics. Ed. Houghton Mifflin Company. Boston.

Feder, H.M. and A.J. Paul. - 1980. Food of the King Crab, Paralithodes camtschatica and the Dungeness Crab, Cancer magister in Cook Inlet, Alaska. Proc. Nat. Shellfish. Assoc., 70 (2): 240-246.

Feder, H.M. and S.C. Jewett. - 1981. Distribution, abundance, community structure and trophic relationships of the nearshore epibenthos of the Kodiak continental shelf. IMS Report, R81-1: $1-215$.

Jewett, S.C. and H.M. Feder. - 1982. Food and feeding habits of the king crab Paralithodes camtschatica near Kodiak Island, Alaska. Mar. Biol., 66: 243-250.

Jewett, S.C. and H.M. Feder. - 1983. Food of the tanner crab Chionoecetes bairdi near Kodiak Island, Alaska, Phillipines (Decapoda Natantia). J. Crust. Biol., 3 (2): 196-207.

Lenna, H. - 1966. Foraminíferos recientes de Ushuaia (Tierra del Fuego, Argentina). Ameghiniana, 4 (9): 311-322 .

Lovrich, G. and J. Vinuesa. - 1993. Reproductive biology of the false southern king crab (Paralomis granulosa, Lithodidae) in the Beagle Channel, Argentina. Fish. Bull., 91: 664-675.

Macpherson, E. - 1988. Revision of the family Lithodidae Samouelle, 1819 (Crustacea, Decapoda, Anomura) in the Atlantic Ocean. Monogr. Zool. Mar., 2: 9-153.

Mc Laughlin, P.A. and J.F. Hebard. - 1961. Stomach contents of the Bering Sea king crab. Int. North Pacific Fish. Comm. Bull., 5: $5-8$

Paul, A.J., H.M. Feder and S.C. Jewett. - 1979. Food of the snow crab Chionoecetes bairdi Rathbun, 1924 from Cook Inlet, Alaska (Decapoda, Majidae). Crustaceana Suppl., 5: 62-68.

Ropes, J.W. - 1988. The food habits of five crab species at Pettaquamscutt River, Rhode Island. Fish. Bull., 87: 197-204.

Ryer, C.H. - 1987. Temporal patterns of feeding by blue crabs (Callinectes sapidus) in a tidal marsh creek and adjacent seagrass meadow in the lower Chesapeake Bay. Estuaries, 10 (2): 136-140.

Stevens, B., D. Armstrong and R. Cusimano. - 1982. Feeding habits of the Dungeness Crab Cancer magister as determined by the index of relative importance. Mar. Biol., 72: 135-145.

Takeuchi, I. - 1968. Food of King Crab (Paralithodes camtschatica) off the west coast of Kamchatka 1958. Bull. Hokkadio Reg. Fish. Res. Lab., 20: 67-75 (1958) (Transl. Ser. Res. Bd. Can., $1193 ;$ 1968)

Vinuesa, J., G. Lovrich and L. Comoglio. - 1989. Temperaturesalinity effects on the development of false southern king crab (Paralomis granulosa). Thalassas, 7: 51-56 . 